\title{
RISCOS
}

\section{Mariana Lage*}

Na série intitulada "riscos", Mariana Lage apresenta um conjunto de sete poemas. O poema "Hazard" faz parte do livro de poesias Le Self Selavy - ainda sem editora e sem previsão de publicação. Já os seis haikais integram o livro Haikais de (não) amor \& outras coisas, a ser publicado pela editora Clãdestina em 2015.
* É jornalista, professora e doutoranda em Estética e Filosofia da Arte (UFMG). Atualmente é bolsista do CNPq, realizando bá́xio doutora com Hans Ulich Gumbrect em Stanford University, Califórnia. Tenford University, Calfórnia. Tem Report, Magazine Lit (Europan Youth Foundas Sup Suplemento Gerais, jornal O Tempo, Jorna Pampulha e Revista Sagarana, alem de catálogos como Mostra Festival Inerneciono Coma proma PUC- professora, trabahou na PUC-Minas (BH e Arcos), e Escola de Música, da UEMG. Em 2013, lançou seu primeiro romance,

\section{marianalagem@gmail.com}


HAZARD

na dança provisória do acaso

era hoje ano novo chinês

na cozinha o roommate falava cantonês

café da manhã sobre cronofobia

e ausência do mito no tempo presente

fora de China Town

antes da dança do dragão

na rua que não sabia o nome

um novo ano se abria

ao final de janeiro

conheci Mei Li

nômade chinesa

fascinada por deslocamentos

da linguagem e caracteres

dos povos e palavras

na dança provisória do ano

um novo acaso se abria 


\section{CAÇA DOR}

amor é linguagem

e também ausência

oroboro impronunciável 
ESFINGE

silêncio exótico

ausência sepulcral

decifra ou devora 
COSMOGONIAS

antes do verbo

puro caos

latentes sementes 


\section{DA LUTA (IV)}

a escrita, a rainha

eu, o pajem

ou o bobo da corte 
DO PARADOXO (II)

vegetariana indecente

no amor livre

um pedaço de carne 


\section{DO LOOPING}

hitchcock reloaded

vertigo ad nauseam

uma ficha que cai 